\title{
Touch DNA Collection Techniques for Non-Porous Surfaces Using Cotton and Nylon Swabs
}

\author{
Salem K Alketbi ${ }^{1,2 *}$ and Goodwin $\mathbf{W}^{1}$ \\ ${ }^{1}$ University of Central Lancashire, Preston, UK \\ ${ }^{2}$ General Department of Forensic Science and Criminology, Dubai Police, Dubai, UAE \\ *Corresponding author: Salem K Alketbi, University of Central Lancashire, Preston, UK
}

\section{ARTICLE INFO}

Received: 幽 June 05, 2021

Published: 䫜 June 15, 2021

Citation: Salem K Alketbi, Goodwin W. Touch DNA Collection Techniques for Non-Porous Surfaces Using Cotton and Nylon Swabs. Biomed J Sci \& Tech Res 36(3)-2021. BJSTR. MS.ID.005862.

Keywords: Forensic Science; Trace DNA; Touch DNA; DNA Recovery; Cotton Swab; Nylon Swab; Qiaamp DNA Investigator Kit; Quantifiler ${ }^{\mathrm{TM}}$ Human DNA Quantification Kit

\begin{abstract}
Touch DNA, commonly known as trace DNA, is widely used in forensic DNA casework. However, touch DNA samples are challenging because of the many variables that can impact the success of obtaining a good quality usable DNA profile. Cotton and nylon flocked swabs are often used to collect touch DNA from surfaces, so this study aimed to test different techniques using cotton (150C) and nylon flocked (4N6FLOQSwabs $®$ ) swabs to collect touch DNA from non-porous surfaces. There was a significant difference amongst the three recovery techniques tested to recover touch DNA with cotton swabs and nylon swabs from textured plastic $(\mathrm{p}<0.001)$, with a nylon swab and $30 \mu \mathrm{l}$ of distilled water being more efficient than a cotton swab with $100 \mu \mathrm{l}$ of distilled water. There was also a significant difference between the four recovery techniques to recover touch DNA from glass surfaces exposed to high humidity and low temperature $\left(5^{\circ} \mathrm{C} / 78 \%\right)$ ( $\mathrm{p}<$ 0.001 ), with a dry cotton or nylon swab being allowing more efficient recovery of touch DNA from non-porous humid surfaces such as glass.
\end{abstract}

\section{Introduction}

Touch DNA, commonly known as trace DNA, is widely used in forensic DNA casework as it is an important tool to link suspects to crime scenes, especially when other types of biological evidence such as body fluids cannot be found. Collecting DNA from fingerprints was first reported in 1997 [1], since then, touch DNA profiling techniques have continuously improved with the advancement of DNA profiling technology and successful collection of touch DNA from a wide range of surfaces and items [2-4]. Nevertheless, touch DNA samples are challenging because of the many variables, such as surface type [5], collection devices $[5,6]$, collection techniques used and environmental factors [79], that can impact the success of obtaining a good quality usable DNA profile. Cotton and nylon flocked swabs are commonly used to collect touch DNA from surfaces and a study by Alketbi and Goodwin [5] reported that cotton swabs (150C) and nylon flocked swabs (4N6FLOQSwabs $®$ ) were similarly effective in collecting
DNA from glass (smooth non-porous surface). Therefore, this study aimed to test different techniques using cotton (150C) and nylon flocked (4N6FLOQSwabs®) swabs to recover touch DNA from non-porous surfaces. Three recovery techniques were evaluated to determine whether the amount of wetting reagent can influence the quantity of collected touch DNA. Also, four recovery techniques were investigated to test the influence of humidity on touch DNA recovery.

\section{Materials and Methods}

\section{Experimental Setup and Deposition}

A participant, previously confirmed as a good shedder, was requested to wash their hands with antibacterial soap, abstain from any activity for 5 minutes, then charge the fingers of both hands with eccrine sweat from behind their ears to load the finger with enough DNA. After a further 5 minutes, the participant was asked 
to touch the surface using their index, middle and ring fingers of both hands one at a time, by applying medium pressure on a $5 \times 7 \mathrm{~cm}$ surface area for one minute. The participant was instructed to repeat the same process for each surface deposition. The surfaces were sterilised before use using $2 \%$ Virkon (viricidal disinfectant) and ultraviolet radiation (UV) for 15 minutes.

\section{Experiment one}

Touch DNA samples deposited on textured plastic (rough nonporous surface) $(n=36)$ were collected immediately after deposition using cotton and nylon swabs. Different quantities of distilled water were used to moisten the swabs via plastic spray bottle technique (developed in Dubai police forensic DNA lab) [8] as follows:

a) Cotton swab with $100 \mu \mathrm{l}$ using a spray bottle $(\mathrm{n}=12)$

b) Nylon swab with $100 \mu$ l using a spray bottle $(n=12)$

c) Nylon swab with $30 \mu$ by pipette as recommended by the manufacturer $(\mathrm{n}=12)$

The DNA was extracted from the swabs heads using the QIAamp® DNA Investigator Kit (Qiagen) according to the manufacturer's instructions and eluted in a final volume of $50 \mu \mathrm{L}$.

\section{Experiment Two}

Touch DNA was deposited on glass (smooth non-porous surface) $(n=36)$ and the surfaces were stored in a fridge for 24 hours before collection $\left(5^{\circ} \mathrm{C} / 78 \%\right)$. The DNA samples were recovered by:

a) Cotton swab moistened with $100 \mu$ l of distilled water by spray bottle $(n=8)$

b) Dry cotton swab $(n=8)$ c) Dry Nylon swab ( $\mathrm{n}=8)$

d) Nylon swab moistened with $30 \mu$ of distilled water by pipette $(n=8)$

The DNA was extracted as before and eluted in a final volume of $50 \mu \mathrm{L}$

\section{DNA Quantification and Analysis}

The DNA samples were quantified using the Quantifiler ${ }^{\circledR}$ Human DNA Quantification Kit, QuantStudio 5 Real-Time PCR (qPCR) and HID Real-Time PCR analysis software v1.3 (Thermo Fisher Scientific) according to the manufacturer's instructions. Statistical analysis was performed with RStudio using factorial analysis of variance (ANOVA). The blanks from surfaces after sterilisation and negative controls for the collection and extraction methods were all negative for DNA.

\section{Results and Discussion}

\section{Experiment one}

There was a significant difference between the three recovery techniques to collect touch DNA with cotton and nylon swabs from textured plastic (F 2,33 = 14.351, p < 0.001) (Figure 1). A nylon swab with $30 \mu \mathrm{l}$ of distilled water (c) was more efficient than a cotton swab with $100 \mu$ l of distilled water (a) to recover touch DNA from rough non-porous surfaces such as textured plastic (means: $\mathrm{a}-0.04$ and $\mathrm{c}-0.05$ all in $\mathrm{ng} / \mu \mathrm{L})(\mathrm{p}<0.05)$. The increased volume of wetting reagent on the nylon swab resulted in some of the DNA sample left on the surface (mean: $0.02 \mathrm{ng} / \mu \mathrm{L})(\mathrm{p}<0.001)$ (Figure 2).

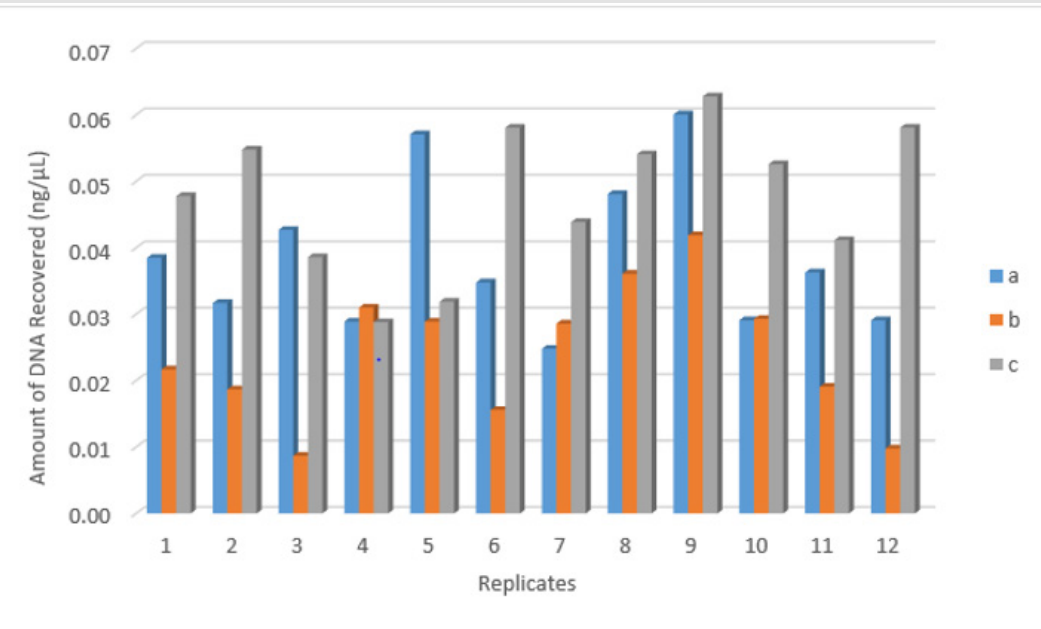

Figure 1: The amount of DNA recovered from twelve replicates $(n=36)$ by each technique:

(a) Cotton swab with $100 \mu$ water,

(b) N=nylon swab with $100 \mu \mathrm{l}$ water and

(c) Nylon swab with $30 \mu \mathrm{l}$ water. 


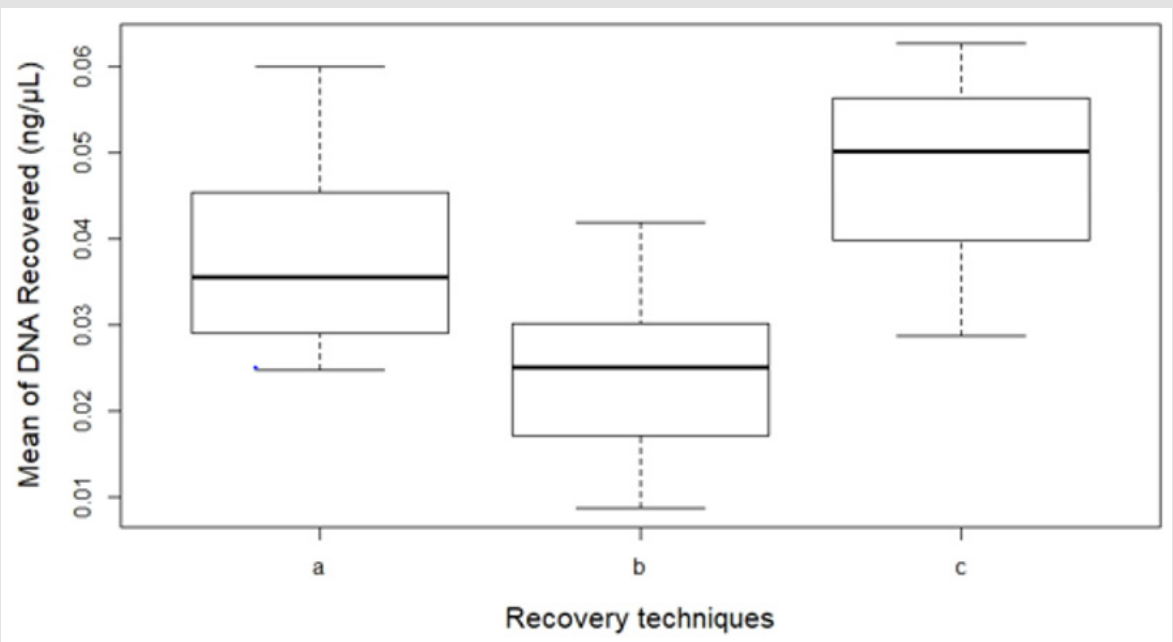

Figure 2: The mean DNA quantity recovered $(n=36)$ by each technique:

(a) Cotton swab with $100 \mu$ l water,

(b) Nylon swab with $100 \mu \mathrm{l}$ water and

(c) Nylon swab with $30 \mu 1$ water. Error bars represent standard error.

\section{Experiment Two}

There was a significant difference between the four recovery techniques tested to collect touch DNA with cotton and nylon swabs from glass surfaces exposed to high humidity and low temperature $\left(5^{\circ} \mathrm{C} / 78 \%\right)(\mathrm{F} 3,28=46.965, \mathrm{p}<0.001)$ (Figure 3$)$. Dry cotton $\mathrm{s}(\mathrm{b})$ or nylon (c) swabs were more efficient to recover touch DNA from non-porous humid surfaces such as glass. Using moist cotton (a) or nylon (d) swabs can leave some of the trace DNA uncollected on the surface (means a $-0.04, b-0.08, c-0.07$ and $d-0.05$ all in $n g / \mu L$ ) (Figure 4).

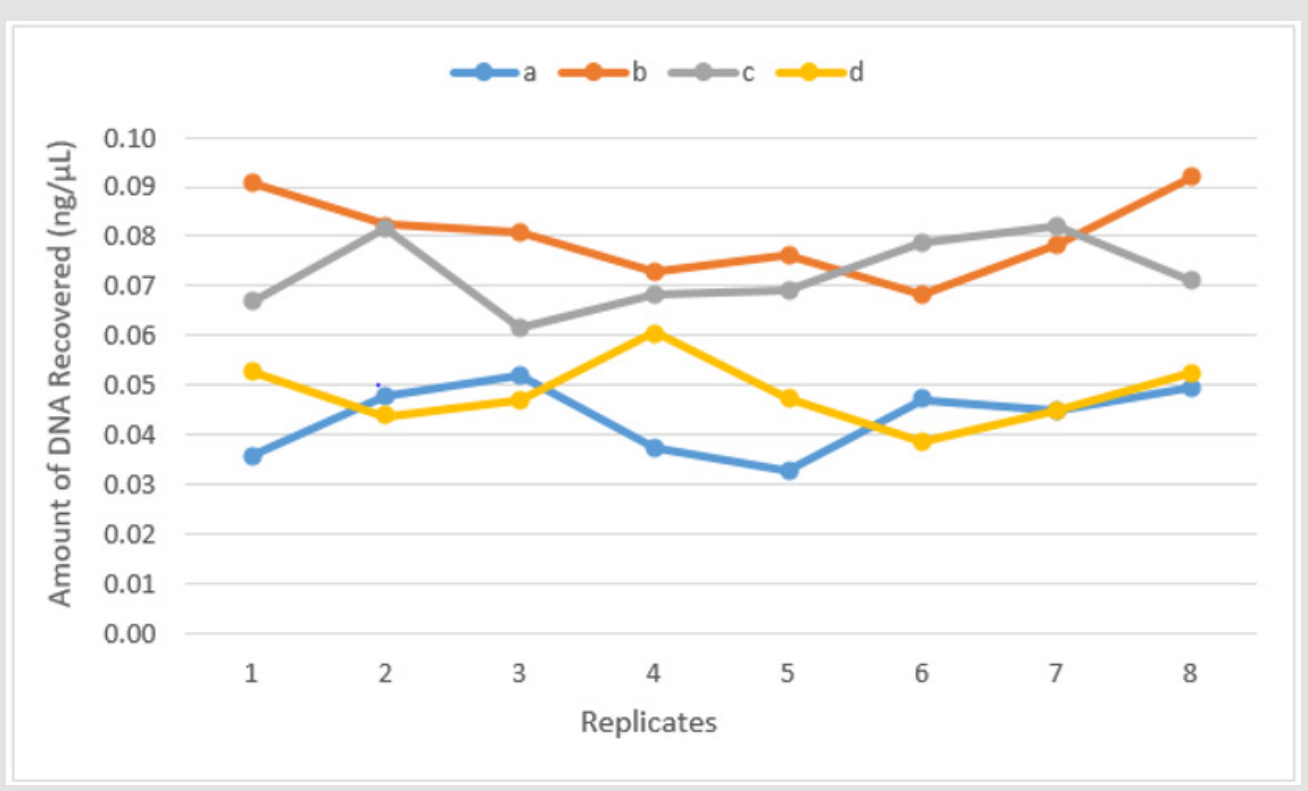

Figure 3: The amount of DNA recovered from eight replicates $(n=32)$ by each technique:

(a) Moist cotton swab,

(b) Dry cotton swab,

(c) Dry nylon swab and

(d) Moist nylon swab. 


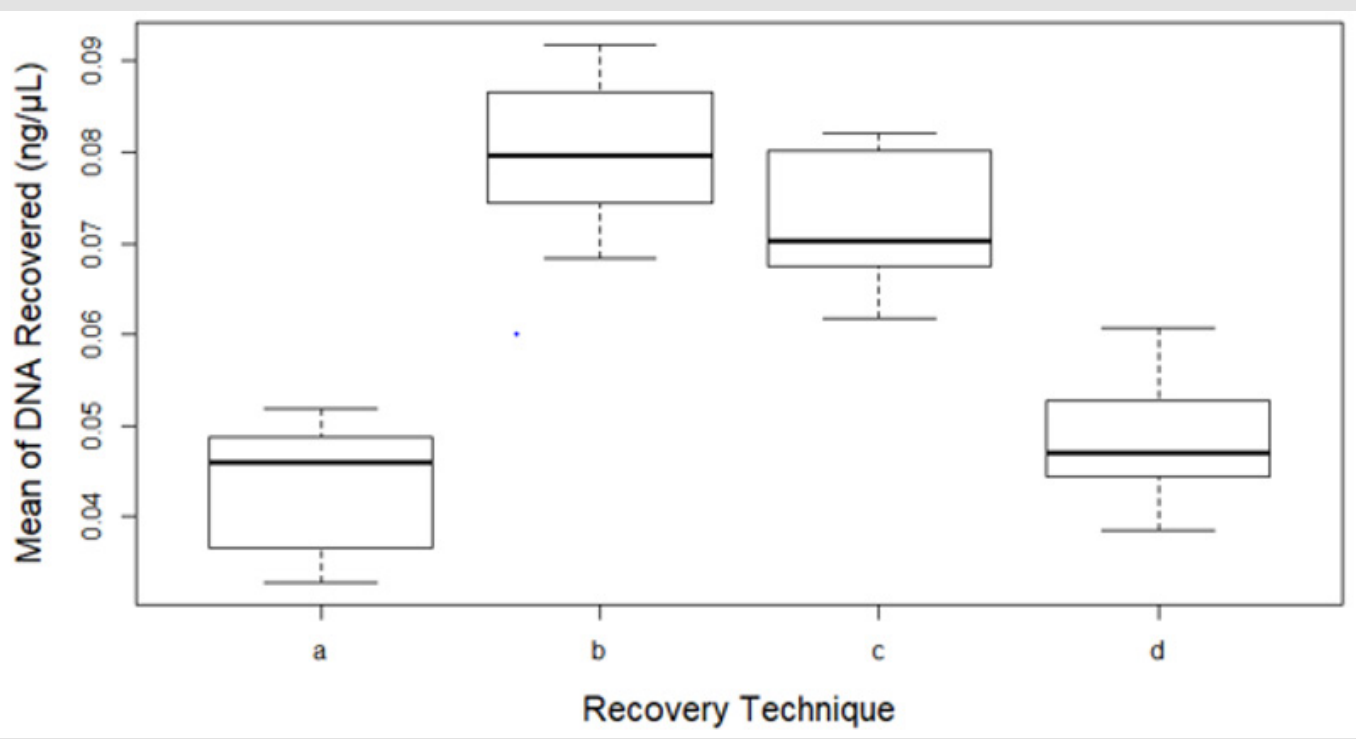

Figure 4: Mean of DNA recovered from eight replicates $(n=32)$ by each technique:

(a) Moist cotton swab,

(b) Dry cotton swab,

(c) Dry nylon swab and

(d) Moist nylon swab. Error bars represent standard error.

\section{Conclusion}

The quantity of wetting agent used for swabs can influence the amount of DNA recovered from non-porous surfaces. Nylon swabs are recommended for the recovery of touch DNA from non-porous, rough surfaces such as textured plastic. Humidity can also influence the quantity of touch DNA recovered from non-porous surfaces such as glass, therefore, dry swabs are recommended to improve DNA recovery.

\section{Acknowledgement}

This study was approved by the General Department of Forensic Science and Criminology in Dubai Police and ethical approval was granted by the School of Forensic and Applied Sciences, and the University of Central Lancashire's Research Ethics Committee (ref. no. STEMH 912). Many thanks to COPAN DIAGNOSTICS INC. for supporting this experiment with free swabs and to ThermoFisher Scientific ${ }^{\mathrm{TM}}$ for product discounts.

\section{References}

1. Van Oorschot RAH, Jones MK (1997) DNA fingerprints from fingerprints. Nature 387: 767.
2. Polley D, Mickiewicz P, Vaughn M, Miller T, Warburton R, et al. (2006) An investigation of DNA recovery from firearms and cartridge cases. J Canadian Soc Forensic Sci 39: 217-228.

3. Oorschot R, Ballantyne K, Mitchell RJ (2010) Forensic trace DNA: A review. Investigative Genetics, 1(1): 14014.

4. Alketbi SK (2018) The affecting factors of Touch DNA. Journal of Forensic Research 9: 424.

5. Alketbi SK, Goodwin W (2019) The effect of surface type, collection, and extraction methods on touch DNA. Forensic Science International. Genetics Supplement Series 7(1): 704-706.

6. Verdon T, Mitchell R, Oorschot R (2014) Swabs as DNA collection devices for sampling different biological materials from different substrates. Journal of Forensic Sciences 59(4): 1080-1089.

7. Alketbi SK, Goodwin W (2019) The effect of time and environmental conditions on Touch DNA. Forensic Science International. Genetics Supplement Series 7(1): 701-703.

8. Alketbi SK, Goodwin W (2019) Validating Touch DNA collection techniques using cotton swabs. J Forensic Res 10: 445.

9. Alketbi SK, Goodwin W (2019) The effect of sandy surfaces on Touch DNA. Forensic Leg Investig Sci 5: 034. 
ISSN: 2574-1241

DOI: 10.26717/BJSTR.2021.36.005863

Salem K Alketbi. Biomed J Sci \& Tech Res

(C) (P) This work is licensed under Creative BY Commons Attribution 4.0 License

Submission Link: https://biomedres.us/submit-manuscript.php

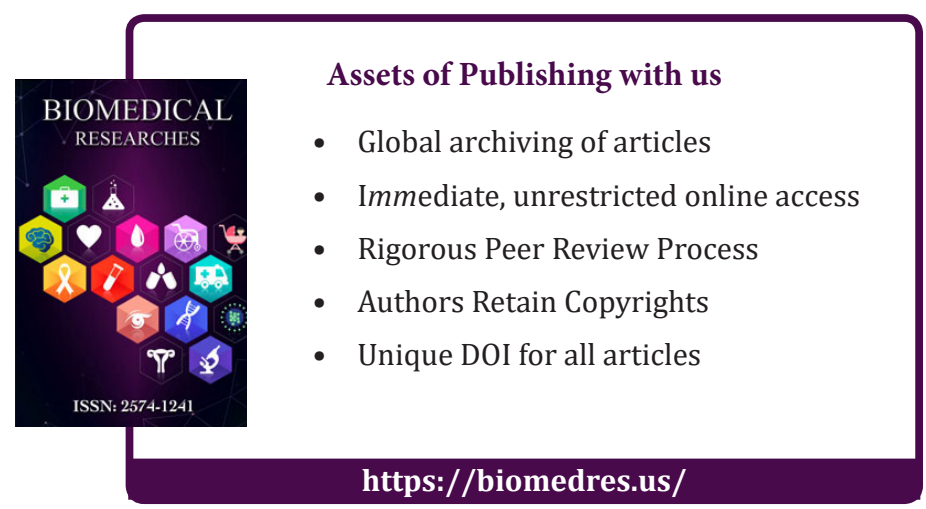

